УДК 659.113 .8

DOI: https://doi.org/10.37320/2415-3583/13.10

\author{
Пащенко О.П. \\ кандидат економічних наук, доцент, \\ Державний університет «Житомирська політехніка» \\ ORCID: htttps://orcid.org/0000-0002-5003-8977 \\ Камінська С.М. \\ студентка, \\ Державний університет «Житомирська політехніка»
}

\title{
ОСОБЛИВОСТІ РЕКЛАМНОЇ ДІЯЛЬНОСТІ ФОП «ЛУГИНА ІГОР ВАСИЛЬОВИЧ» ТА ШЛЯХИ ПІДВИЩЕННЯ ЇЇ ЕФЕКТИВНОСТІ
}

\begin{abstract}
У статті проаналізовано особливості рекламної діяльності ФОП «Лугина Ігор Васильович». Підприємство діє на вітчизняному та закордонному ринку. Виробляє найширшу гаму чайної продукиї, використовуючи не тільки власну сировину, але й імпортну - високої якості. Визначено конкурентні переваги досліджуваного підприємства - замкнутий виробничий иикл. Реалізуючи рекламну кампанію, ФОП «Лугина Ігор Васильович» ставить перед собою такі цілі, як: збільшення обсягів продажу; популяризація торгової марки; зміна поведінки споживача через інформування про присвоєння продукиї фірми сертифікату якості ISO 9001 ma ISO 22000. Рекламна кампанія включає в себе: випуск буклетів; рекламу в пресі (журнали, переважно будівельна та бізнес-тематика); рекламу в Internet (розроблення сайту, посилання на сайт); поштову розсилку; участь у телепередачах; зовнішню рекламу; рекламу на радіо. Визначено слабкі місия рекламної діяльності досліджуваного підприємства. Розроблено пропозииії щзодо підвищення ї̈ ефективності. Запропоновано посилити використання засобів PR та корпоративної сочіальної спеціальності.
\end{abstract}

Ключові слова: реклама, інструменти реклами, рекламна кампанія, рекламна політика, ефективність реклами.

Постановка проблеми. Нині перед підприємствами стоїть доволі складне завдання привернення уваги споживачів та формування довгострокової прихильності до продукції чи послуг підприємства. Маркетологи та спеціалісти зі збуту застосовують різноманітні підходи та засоби з метою ознайомлення покупців із продукцією, спонукання повторної купівлі, формування позитивного іміджу підприємства. Одним із важливих інструментів маркетингової діяльності залишається реклама. Проте потрібно пам'ятати, що вибір виду та інструментів реклами буде залежати від виду продукції, особливостей діяльності, сегменту, який обслуговує підприємство.

Аналіз останніх досліджень і публікацій. Вагомий науковий внесок в опрацювання проблем рекламної діяльності зробили зарубіжні та вітчизняні дослідники, зокрема Ю.С. Бернадська [1], В.В. Божкова, Ю.М. Мельник [2], А.Г. Владимирська [3], Ю.Б. Іванов [4], Е.В. Ісаєнко, А.Г. Васильєв [5], О.С. Кузьмін, С.Б. Романишин, Н.І. Горбаль [6], М.Д. Пазуха, М.В. Ігнатович [7] та інші. Проте додаткових досліджень потребують саме практичні аспекти використання інструментів реклами та реалізації рекламної кампанії підприємства.

Метою статті $є$ дослідження особливостей рекламної діяльності ФОП «Лугина Ігор Васильович», виявлення слабких місць та розроблення пропозицій щодо підвищення іiї ефективності.

Виклад основного матеріалу. Рекламна діяльність нині $\epsilon$ важливою складовою частиною діяльності підприємств та є однією із найпотужніших галузей економіки розвинених країн. На рекламну діяльність покладається важлива місія ознайомлення споживачів із продукцією чи послугами підприємства, формування довгострокової прихильності споживачів, підвищення обсягів збуту, формування культури споживання, пози- тивного іміджу на ринку та ін. Під час розроблення реклами та формування рекламного звернення важливо пам'ятати про іï вплив на підсвідомість та кругозір людей, враховувати моральні та культурні цінності, традиції, що склались у суспільстві. Сьогодні змінюються орієнтири реклами, вона повинна бути корисною, спрямовуватися на пропагування здорового способу життя, зачіпати важливі соціальні аспекти життя суспільства, звертати увагу на важливість піклування про навколишнє середовище та покращення екології.

Своєрідність українського ринку й особливості масової аудиторії не дають змоги сьогодні цілком використовувати модель реклами, розроблену західними дослідниками на основі вікової історії розвитку реклами в умовах вільного ринку. Отже, для створення реклами, яка викликає позитивні емоції і досягає планованого результату, необхідно враховувати особливості українських реалій і відповідним чином адаптувати досягнення світової рекламної практики [4].

Проаналізуємо рекламну діяльність на прикладі підприємства ФОП «Лугина Ігор Васильович», яке займається реалізацією чайної продукції (чай чорний, зелений, білий, фруктовий, ароматизований) в межах України та здійснює поставки за кордон. Основними торговельними партнерами ФОП «Лугина Ігор Васильович» виступають Росія, Польща, Латвія, Білорусь. Уся продукція сертифікована, відповідає міжнародним стандартам ISO 9001 та ISO 22000.

ФОП «Лугина Ігор Васильович» оцінює себе як потенційного конкурента таких значних операторів, як «Ізівендінг», «Мономах», «Віденська кава», «Екопродукт», «Еспресо Маніяки», «Ахмад Ті» тощо, і не тільки на ринку України. Найголовніша конкурентна перевага досліджуваного підприємства - це замкнутий виробничий цикл. Досліджуване підприємство виробляє найширшу гаму чайної продукції, використову- 
ючи не тільки власну сировину, але й імпортну - високої якості.

Оскільки основною продукцією підприємства є чай та чайна продукція, то сегмент ринку - це широкі маси населення різних вікових груп. Як свідчать дані маркетингових досліджень, під час вибору чаю споживачі орієнтується на відомість торгової марки, потім на смак, вид фасовки, а далі на ціну, саме тому треба більше уваги приділяти рекламі і вибору рекламної стратегії. Рекламна кампанія ФОП «Лугина Ігор Васильович» спрямована на досягнення таких цілей, як: збільшення обсягів продажу; популяризація торгової марки; зміна поведінки споживача через інформування про присвоєння продукції фірми сертифікату якості ISO 9001 та ISO 22000.

Рекламна кампанія досліджуваним підприємством проводиться на постійній основі. Треба відзначити, що інтенсивна рекламна кампанія велася підприємством у 2014-2015 рр., реклама транслювалася по національному телебаченню, основною метою їі була розкрутка нових видів чаю і популяризація торгової марки загалом. У 2019 р. рекламна кампанія ФОП «Лугина Ігор Васильович» включала в себе: випуск буклетів; рекламу в пресі (журнали, переважно будівельна та бізнес-тематика); рекламу в Internet (розроблення сайту, посилання на сайт); поштову розсилку; участь у телепередачах; зовнішню рекламу; рекламу на радіо.

Бюджет рекламної кампанії на цьому підприємстві обчислюється методом у «відсотках до суми продажів»: у визначеному процентному відношенні або до суми продажів (поточних чи очікуваних), або до ціни реалізації товару. Цей метод змушує керівництво враховувати взаємозв'язок між витратами на рекламу, ціною реалізації товару і сумою прибутку в розрахунку на товарну одиницю.

Бюджет реклами ФОП «Лугина Ігор Васильович» у 2019 році наведено у таблиці 1 .

ФОП «Лугина Ігор Васильович» під час реалізації рекламної кампанії використовує не один носій, а декілька. Вважаємо, що таке одночасне поєднання різних носіїв реклами $є$ ефективним, оскільки дає змогу охопити широку аудиторію споживачів. Одним із головних завдань, які покладаються на рекламу, є інформатизація споживачів про особливості товарів чи послуг, їхні переваги, товарну марку, заходи корпоративної соціальної відповідальності. Коли споживачі обізнані про діяльність підприємства, спрацьовує фактор імпульсної купівлі.
Також великого значення підприємство надає розповсюдженню інформації про отримання сертифікату якості ISO 9001 та ISO 22000 на власну продукцію, проводить дегустації у супермаркетах, на ринках, під час масових заходів, використовує систему знижок для постійних клієнтів, розіграші та акції.

Білборди 3 рекламою компанією розміщено у м. Київ - в основному на місцях в'їзду/виїзду. Для реклами в інтернеті було розроблено сайт (www.lygina. com.ua), на якому висвітлено детальну інформацію про наявний асортимент товарів, особливості діяльності компанії та акції, що проводяться. Для посилань на сайт використовується реклама у вигляді текстових рекламних посилань.

Показ рекламних повідомлень «Лугина» в інтернеті здійснюється завдяки:

1. Розміщенню рекламної інформації на професіональних сайтах (зокрема, у 2019 році реклама давалася за допомогою Яндекс, Директ та Google Adwords).

2. Реєстрації інформації в пошукових машинах та каталогах (натепер сайт зареєстровано в Яндексі, Гуглі, Рамбрелі, Меті, та інших пошукових системах).

- Показу банерної реклами: на популярних сайтах (Бігмір, Укр.Нет); на тематичних сайтах; у спеціальних банерних цілях.

3. Обміну посиланнями на сайтах партнерів (на сайтах фірм із продажу чайної продукції, а також сайтах виробників продукції).

4. Організації рекламних розсилок за допомогою електронної пошти.

5. Розміщенню рекламних публікацій:

- на конференціях;

- у списках розсилки;

- на дошках оголошень.

Отже, у процесі рекламної кампанії задіяні усі можливості маркетингових комунікацій. Внаслідок цього все більше людей звертається за чайними товарами саме до ФОП «Лугина Ігор Васильович», коло постійних клієнтів зростає, а разом 3 ним i прибутки, що дає можливість розширювати спектр діяльності. Проте залишаються невичерпаними досить великі можливості залучення потенційних клієнтів, зокрема аналіз звернень споживачів засвідчив, що деякі клієнти цікавляться цінами на продукцію, але їi не купують. Ці потенційні споживачі й повинні стати основною цільовою аудиторією наступних рекламних кампаній. Крім того, в межах рекламної кампанії мало приділяється уваги PR-кампаніям.

Таблиця 1 - Бюджет реклами ФОП «Лугина Ігор Васильович» на 2019 рік

\begin{tabular}{|l|c|}
\hline \multicolumn{1}{|c|}{ Засіб реклами } & Сума, грн. \\
\hline 1. Реклама на телебаченні & 25000 грн. \\
\hline 2. Реклама на радіо & 10000 грн. \\
\hline 3. Зовнішня реклама (реклама на транспорті, білборди) & 7000 грн. \\
\hline 4. Поштова розсилка (Вігесі Маіі) & 5000 грн. \\
\hline 5. Поліграфічна продукція: оглядовий та спеціалізований рекламний буклет, презентаційні брошури & 4000 грн. \\
\hline 6. Рекламно-сувенірна продукція (ручки, папки, ділові тижневики). & 5000 грн. \\
\hline 7. Реклама в мережі Інтернет & 5000 грн. \\
\hline 8. Участь у виставках, конференціях & 6000 грн. \\
\hline 9. Непередбачені витрати & 5000 грн. \\
\hline РАЗОМ & 70000 грн. \\
\hline
\end{tabular}


Стратегія рекламної кампанї досліджуваного підприємства спрямована на досягнення престижу торгової марки та формування довіри у споживача до якості продукції.

Інтенсивна рекламна кампанія (реклама по телебаченню + реклама по радіо + реклама в пресі + зовнішня реклама) є досить дорогою, тому зараз реклама підприємства має нагадувальний та стимулюючий характер.

У таблиці 2 наведено результати рекламної кампаніï 2018-2019 pp.

\section{Таблиця 2 - Результати діяльності ФОП «Лугина Ігор Васильович»} під час рекламної кампанії у 2018-2019 рр.

\begin{tabular}{|l|c|c|}
\hline \multicolumn{1}{|c|}{ Показники } & $\mathbf{2 0 1 8}$ & $\mathbf{2 0 1 9}$ \\
\hline Обсяг продажу, тис. грн. & 980 & 965 \\
\hline Витрати на рекламу, тис. грн. & 63,2 & 70 \\
\hline Прибуток, тис. грн. & 250,1 & 240,1 \\
\hline
\end{tabular}

Основними перевагами вибраної рекламної стратегії ФОП «Лугина Ігор Васильович» є:

1. Реклама у пресі набагато дешевша, ніж реклама на телебаченні. Крім того, має широке охоплення території.

2. Активно використовуються такі засоби реклами на місці продажу, як вітрини, вивіски, знаки, упакування, планшети.

3. У процесі реалізації рекламної діяльності ФОП «Лугина Ігор Васильович» використовує зовнішню рекламу на вулицях і площах міст, населених пунктів, а також рекламу на транспорті.

4. Імідж-рекламу ФОП «Лугина Ігор Васильович» активно реалізує через проведення ярмарок, спонсорство та організації презентацій.

Узагальнюючи проведені дослідження, пропонуємо такі заходи щодо удосконалення планування й організації рекламної діяльності ФОП «Лугина Ігор Васильович», як:
- розміщення статей про корисність продукції ФОП «Лугина Ігор Васильович», акцентуючи увагу на привабливості здорового способу життя. Нині традиційні засоби реклами не здійснюють бажаного впливу на споживачів. Тому підприємства вдаються до використання таких засобів комунікацій, які $є$ прихованими для споживача i водночас дають змогу сформувати довгострокову прихильність споживачів до продукції чи послуг. Так, наприклад, через розміщення статей, в яких висвітлюється інформація про особливості продукції, іiї якість, відгуки споживачів або правила організації чайної церемонії;

- реалізація заходів корпоративної соціальної відповідальності (КСВ), зокрема підтримка розвитку дитячого спорту у м. Київ, пропагування здорового способу життя серед молоді. Як показує практичний досвід, впровадження заходів корпоративної соціальної відповідальності дає змогу досягнути таких позитивних результатів, як: зміцнення позицій бренду та іміджу компанії за результатами отримання реального публічного визнання; збільшення обсягу продажів та частки ринку внаслідок масової підтримки населенням саме тих компаній, які постійно публічно дотримуються КСВ; оптимізація операційних процесів та зменшення виробничих витрат як певний зиск від імплементації КСВ; налагодження та побудова дієвих відносин з іншими компаніями, державними структурами та комерційними організаціями; поліпшення фінансових та економічних показників діяльності.

Висновки. Реклама відіграє важливу роль у стимулюванні збуту продукції та послуг підприємства, у формуванні позитивного іміджу на ринку та створенні довгострокової прихильності споживачів. Класична реклама втратила свою актуальність, є дорогою та не завжди дає бажаний результат. Тому підприємствам потрібно акцентувати увагу на сучасних, малобюджетних, проте ефективних засобах маркетингових комунікацій, що мають соціальну спрямованість.

\section{Список використаних джерел:}

1. Основи реклами : Підручник / Ю.С. Бернадська та ін. ; за ред. Л.М. Дмитрієвої. Київ : Наука, 2015. 281 с.

2. Божкова В.В., Мельник Ю.М. Реклама та стимулювання збуту : Реком. МОНУ як навч. посібник для студ. ВНЗ. Київ : ЦУЛ, 2010. 200 с.

3. Владимирська А.Г., Владимирський П.А. Реклама : навч. посіб. Київ : Кондор, 2016. 334 с.

4. Іванов Ю.Б. Теоретичні основи конкурентної стратегії підприємства : монографія / За заг. ред. Ю.Б. Іванова, О.М. Тищенка. Х.: ВД “ІНЖЕК”, 2006. 384 c.

5. Ісаєнко Е.В., Васильєв А.Г. Організація і планування рекламної діяльності : Навч. посіб. для вузів. Москва : ЮНІТІДАНА, 2014. $252 \mathrm{c}$.

6. Кузьмін О.С. Рекламна стратегія підприємства : монографія / О.С. Кузьмін, С.Б. Романишин, Н.І. Горбаль. Львів : Видавництво Національного університету «Львівська політехніка», 2014. 168 с.

7. Пазуха М.Д., Ігнатович М.В. Реклама у підприємницькій діяльності : навч. посіб. Київ : ЦУЛ, 2015. 176 с.

\section{References:}

1. Bernadska Yu.S., Marochkina S.S., Smotrova L.F. (2015). Osnovy reklamy [Basics of advertising]. Kyiv: Science. (in Ukrainian)

2. Bozhkova V.V, Melnik Yu. M. (2010). Reklama ta stymuljuvannja zbutu [Advertising and sales promotion]. Kyiv: CUL. (in Ukrainian)

3. Vladimirskaya A.G., Vladimirsky P.A. (2016). Reklama [Advertising]. Kyiv: Condor. (in Ukrainian)

4. Ivanov Yu.B. (2006). Teoretychni osnovy konkurentnoi' strategii' pidpryjemstva [Theoretical foundations of competitive strategy of the enterprise]. H.:VD "INZHEK". (in Ukrainian)

5. Isaenko E.V., Vasiliev A.G. (2014). Orhanizatsiia i planuvannia reklamnoi diialnosti [Organization and planning of advertising activities]. Moskva: UNITY-DANA. (in Ukrainian)

6. Kuzmin O.E., Romanyshyn S.B., Horbal N.I. (2014). Reklamna stratehiia pidpryiemstva: monohrafiia [Advertising strategy of the enterprise: monograph]. Lviv: Lviv Polytechnic National University Publishing House. (in Ukrainian)

7. Pazukha M.D., Ighnatovych M.V. (2015). Reklama u pidpryiemnytskii diialnosti [Advertising in business]. Kyiv: TSUL. (in Ukrainian) 
Pashchenko Olga, Caminska Sofiya

Zhytomyr Polytechnic State University

\section{FEATURES OF ADVERTISING ACTIVITY OF PRIVATE ENTREPRENEUR LUGINA IGOR VASYLIOVYCH AND WAYS TO INCREASE ITS EFFICIENCY}

The features of advertising activities of private entrepreneur "Lugina Igor Vasyliovych" are analyzed in the article. The company operates in the domestic and foreign markets. It produces the widest range of tea products, using not only its own raw materials, but also imported - high quality. The competitive advantages of the researched enterprise are defined, it's the closed production cycle. Implementing an advertising campaign, private entrepreneur "Lugina Igor Vasyliovych" has the following goals: increase sales; brand promotion; change of consumer behavior by informing them about the assignment of the company's products to the quality certificate ISO 9001 and ISO 22000. The advertising campaign includes: issue of booklets; advertising in the press (magazines, mainly construction and business topics); advertising on the Internet (site development, links to the site); mailing; participation in TV shows; outdoor advertising; radio advertising. The strategy of the advertising campaign of private entrepreneur "Luhyna Ihor Vasylyovych" was evaluated and it was revealed that it is aimed at achieving the prestige of the brand and building consumer confidence in the quality of products. Weaknesses of advertising activity of the researched enterprise are defined. Proposals have been developed to increase its efficiency. It is proposed to strengthen the use of PR tools, in particular by posting articles about the usefulness of the products of private entrepreneur "Luhyna Igor Vasyliovych", emphasizing the attractiveness of a healthy lifestyle. Also, a number of measures have been developed and proposed within the implementation of the policy of corporate social specialty in order to form a positive image of the company, including support for the development of children's sports in Kyiv, promoting a healthy lifestyle among young people. The implementation of the proposed measures will contribute to the achievement of the following positive results: strengthening the brand's position and the company's image as a result of obtaining real public recognition; increase in sales volume and market share due to mass support by the population of those companies that constantly publicly adhere to CSR; optimization of operational processes and reduction of production costs as a certain benefit from the implementation of CSR; establishing and building effective relationships with other companies, government agencies and commercial organizations; improving financial and economic performance.

Key words: advertising, advertising tools, advertising campaign, advertising policy, advertising efficiency.

JEL classification: M37 